\title{
REVISÃO
}

\section{Etiology and epidemiology of Pythium root rot in hydroponic crops: Current knowledge and perspectives}

\author{
John Clifford Sutton ${ }^{1 *}$, Coralie Rachelle Sopher ${ }^{1}$, Tony Nathaniel Owen-Going ${ }^{1}$, Weizhong Liu ${ }^{1}$, \\ Bernard Grodzinski ${ }^{1}$, John Christopher Hall ${ }^{1}$, Ruth Linda Benchimol ${ }^{2}$
}

\author{
${ }^{1}$ Department of Environmental Biology, University of Guelph, Guelph, ON, Canada, N1G 2W1.; ${ }^{2}$ Embrapa Amazônia Oriental, Caixa Postal \\ 48, 66017-970, Belém, PA, Brasil \\ *Autor para correspondência: jcsutton@uoguelph.ca \\ Data de chegada: 10/05/2005. Aceito para publicação em: 23/11/2005.
}

\begin{abstract}
Sutton, J.C.; Sopher, C.R.; Owen-Going, T.N.; Liu, W.; Grodzinski, B.; Hall, J.C.; Benchimol, R.L. Etiology and epidemiology of Pythium root rot in hydroponic crops: current knowledge and perspectives. Summa Phytopathologica, v.32, n.4, p.307-321, 2006.

The etiology and epidemiology of Pythium root rot in hydroponically-grown crops are reviewed with emphasis on knowledge and concepts considered important for managing the disease in commercial greenhouses. Pythium root rot continually threatens the productivity of numerous kinds of crops in hydroponic systems around the world including cucumber, tomato, sweet pepper, spinach, lettuce, nasturtium, arugula, rose, and chrysanthemum. Principal causal agents include Pythium aphanidermatum, Pythium dissotocum, members of Pythium group $\mathrm{F}$, and Pythium ultimum var. ultimum. Perspectives are given of sources of initial inoculum of Pythium spp. in hydroponic systems, of infection and colonization of roots by the pathogens, symptom development and inoculum production in host roots, and inoculum dispersal in nutrient solutions. Recent findings that a specific elicitor produced by $P$. aphanidermatum may trigger necrosis (browning) of the roots and the transition from biotrophic to necrotrophic infection are considered. Effects on root rot epidemics of host factors (disease susceptibility, phenological growth stage, root exudates and phenolic substances), the root environment (rooting media, concentrations of

dissolved oxygen and phenolic substances in the nutrient solution, microbial communities and temperature) and human interferences (cropping practices and control measures) are reviewed. Recent findings on predisposition of roots to Pythium attack by environmental stress factors are highlighted. The commonly minor impact on epidemics of measures to disinfest nutrient solution as it recirculates outside the crop is contrasted with the impact of treatments that suppress Pythium in the roots and root zone of the crop. New discoveries that infection of roots by $P$. aphanidermatum markedly slows the increase in leaf area and whole-plant carbon gain without significant effect on the efficiency of photosynthesis per unit area of leaf are noted. The platform of knowledge and understanding of the etiology and epidemiology of root rot, and its effects on the physiology of the whole plant, are discussed in relation to new research directions and development of better practices to manage the disease in hydroponic crops. Focus is on methods and technologies for tracking Pythium and root rot, and on developing, integrating, and optimizing treatments to suppress the pathogen in the root zone and progress of root rot.
\end{abstract}

Additional keywords: leprosis, citrus, CiLV-C, CiLV-N, Brevipalpus spp.

\section{RESUMO}

Sutton, J.C.; Sopher, C.R.; Owen-Going, T.N.; Liu, W.; Grodzinski, B.; Hall, J.C.; Benchimol, R.L. Etiology and epidemiology of Pythium root rot in hydroponic crops: Current knowledge and perspectives. Summa Phytopathologica, v.32, n.4, p.307-321, 2006.

A etiologia e a epidemiologia da podridão radicular causada por Pythium spp. em cultivo hidropônico são revisadas com ênfase em conhecimentos e conceitos considerados importantes para o manejo de doenças em estufas comerciais. A podridão radicular causada por Pythium continuamente ameaça a produtividade de diversas culturas em sistemas hidropônicos, incluindo pepino, tomate, pimentão, espinafre, alface, capuchinha, rúcula, rosa, e crisântemo. Os principais agentes causais incluem Pythium aphanidermatum, Pythium dissotocum, espécies de Pythium do grupo F e Pythium ultimum var. ultimum. São apresentadas e discutidas as principais fontes do inóculo primário de Pythium spp. em sistemas hidropônicos, os processos de infecção e colonização de raízes pelos patógenos, o desenvolvimento de sintomas, a produção de inóculo em raízes, e a dispersão do inóculo na solução nutritiva. Descobertas recentes da existência de um elicitor produzido especificamente por $P$. aphanidermatum que pode provocar a necrose (descoloração) das raízes infectadas e a transição da infecção da fase biotrofica para necrotrofica são consideradas. Efeitos de fatores ligados ao hospedeiro (susceptibilidade à doença, estádio fenológico, exsudatos radiculares, compostos fenólicos), ao ambiente radicular (meio de enraizamento, concentrações de oxigênio dissolvido e compostos fenólicos na solução nutritiva, co- 
munidades microbianas e temperatura) e as interferências humanas (práticas de cultivo e medidas de controle) sobre as epidemias de podridão radicular causados por Pythium spp. são revistos. Resultados recentes que demostram um aumento da predisposição das raízes ao ataque de Pythium induzida por estresses ambientais são destacados. O impacto das medidas usadas para a desinfestação da solução nutritiva recirculando fora do cultivo sobre a epidemia da doença é comparada com o impacto de tratamentos que suprimem Pythium nas raízes e na zona radicular da cultura. Novas descobertas de que a infeção de raízes por $P$. aphanidermatum reduz o crescimento da área foliar e o acúmulo de carbono na planta inteira, sem alterar significativamente a eficiência da fotossíntese por unidade de área foliar, são destacadas. O conhecimento e entendimento da etiologia e epidemiologia da podridão radicular, e seus efeitos na fisiologia da planta, são dicutidos em relacão às novas perspectivas das pesquisas e ao desenvolvimento de melhores práticas para o manejo da doença em cultivo hidropônico. Ênfase é dada nos métodos e tecnologias para a detecção de Pythium tanto na solução nutritiva quanto nas raízes e no desenvolvimento, integração e otimização dos tratamentos para suprimir o patógeno na zona radicular e o progresso da podridão das raízes.

Palavras-chaves adicionais: Pythium aphanidermatum, Pythium dissotocum, zona radicular, solução nutritiva, desinfecção, crescimento da parte aérea, predisposição ambiental, compostos fenólicos.

Pythium root rot is ubiquitous and frequently destructive in almost all kinds of plants produced in hydroponic systems, including cucumber, tomato, sweet pepper, spinach, lettuce, arugula, and roses. In Canada, root rot epidemics continually threaten the productivity of greenhouse vegetables and flowers such as chrysanthemums in hydroponic troughs on mobile benches which, compared to ground beds, would have allowed substantial increases in production efficiencies. Pythium root rot is also considered a potential threat to plant biomass production in manned space vehicles and at extraterrestrial installations in projected space missions $(41,70$, 92). Indeed Pythium has already been encountered on plant materials in space vehicles operated in earth orbit. In greenhouse and growth room studies, Pythium root rot became severe in hydroponic tobacco, Arabidopsis and antirrhinum, which are key plants employed for genetic, molecular and physiological studies (N. Ortiz, W. Liu, \& J.C. Sutton, 2003 unpublished observations). Thus, the problem of Pythium root rot needs to be resolved in diverse commercial and research situations.

Management of Pythium root rot in the production of hydroponic crops is generally a difficult challenge. Extraordinary sanitation measures do not necessarily exclude or destroy the causal pathogens, and once initiated, epidemics are difficult to contain. Recent advances in knowledge and understanding of the etiology and epidemiology of root rot, and in methods and approaches to control the disease, are providing a framework for major improvements in root rot management and in the overall health and productivity of hydroponic crops. This review considers recent findings in small-scale and commercial hydroponic systems in relation to methods and technologies to optimize root rot management.

\section{Hydroponic systems and the root environment}

In cool temperate climates such as in southern Canada, hydroponic crops normally are grown in greenhouses with sophisticated systems for controlling conditions of the microclimate (temperature, humidity, carbon dioxide, light) and nutrient solution composition $(\mathrm{pH}$, and dissolved oxygen concentration). On the other hand, in warm or tropical climates such as in São Paulo and Belém, Brazil, hydroponic crops are grown without sophisticated climate control, but with at least partial protection against harsh weather conditions, and with standardized nutrient solution. In such climates, hydroponic crops generally are produced in greenhouses constructed with wooden or concrete frames and covered on top with clear plastic film to exclude rain, and, in some instances, with screening against intense sunlight. Wooden lattice or plastic film may be used on one or more sides for protection against wind and rain.

Roots of hydroponic plants either grow in the nutrient solution only, or in rockwool (stone wool), coconut fiber, sawdust, sand or other medium that is irrigated with nutrient solution. No soil is employed. Some crops, especially flowers and other ornamentals, are grown in single- or multi-plant containers with a rooting medium that is irrigated via tubing from above or by means of a trough below the container. Hydroponic vegetables often are grown in slabs or blocks of rockwool, coconut fiber or other medium enclosed in plastic film and fed with nutrient solution via plastic capillary tubes (Fig. 1). Others are grown in troughs formed from black-on-white plastic on the greenhouse floor, or in troughs of rigid plastic positioned at ground level or on benches. Nutrient solution is circulated through the troughs, which may or may not contain a rooting medium. Troughs usually are arranged in parallel and interconnected into large systems that accommodate thousands or tens of thousands of plants (Fig. 2). Lettuce, arugula (Eruca sativa Mill. or Eruca versicaria subsp. sativa Shallot), Nasturtium officinalis R.BR., and other small-sized plants are sometimes grown on gently sloping sheets of corrugated plastic or other material, and nutrient solution is allowed to flow down channels in the sheets and through the root zone of the plants. Nutrient solution in the various systems is either circulated once or is continuously recirculated. In Canada, the hydroponics crops industry is in transition from continuous or frequent discharge of used nutrient solutions into the environment to continuous recirculation through root zones of crops. Hydroponic systems are being adapted for continuous recirculation over concerns about pollution of water resources with greenhouse effluents and to conform with new environmental legislation.

\section{Causal agents of pythium root rot}

The main species of Pythium reported to cause root rot in hydroponic crops are P. aphanidermatum (Edson) Fitzp., P. dissotocum Drechsler, P. ultimum Trow var. ultimum, and members of Pythium group F (4, 14, 23, 28, 39, 61, 68, 73, 82, 86, 106). Pythium aphanidermatum, $P$. dissotocum, and Pythium $\mathrm{F}$ produce abundant zoospores, while P. ultimum var. ultimum produces zoospores only rarely. Zoospores are produced asexually in sporangia and associated vesicles. The sporangia of $P$. aphanidermatum are filamentous and lobed (or inflated), while those of $P$. dissotocum are filamentous, dendroidly branched and not inflated or slightly inflated (112). Pythium group $\mathrm{F}$ is characterized by filamentous non-inflated sporangia (82, 100). Each of the species is able to produce oospores (thick-walled sexual spores) in infected roots and in the rhizosphere. These Pythium spp. each attack a wide range of host plants. A few other species, 


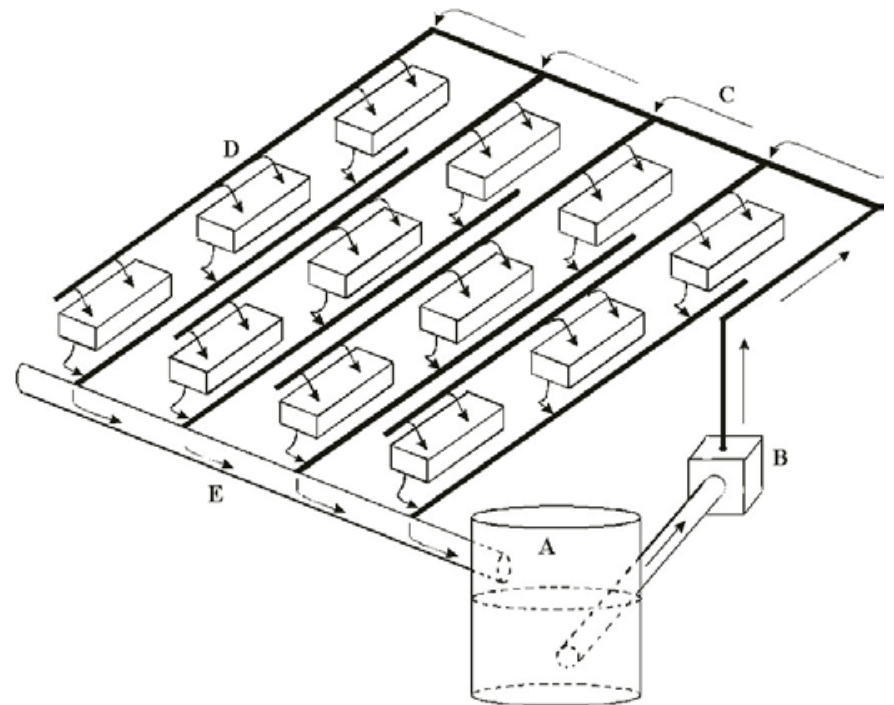

Figure 1. A schematic diagram of a hydroponic system with rockwool slabs (symbolized by the twelve blocks) and recirculating nutrient solution. The solution is circulated in the direction of the arrows from a mixing tank (A) to a disinfestation unit (B), the crop zone (C) and area with rockwool blocks (D), and subsequently drains into a collection pipe (E) in which the solution is returned to the mixing tank. The solution is recharged with water and nutrients in the tank, and may be treated in the disinfestation unit to destroy pathogen propagules, such as by heat pasteurization, filtration, or ultraviolet radiation.

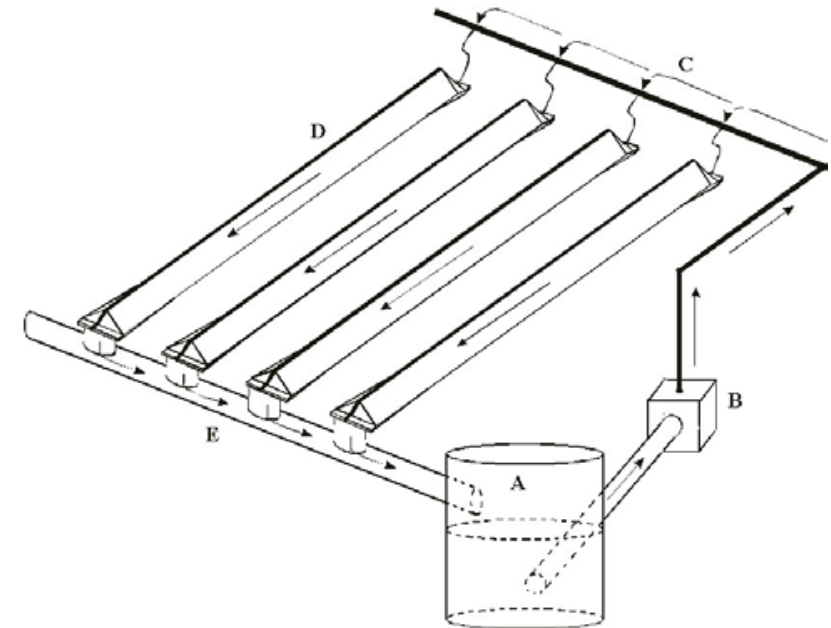

Figure 2. A schematic diagram of a hydroponic system with troughs and recirculating nutrient solution. The solution is circulated in the direction of the arrows from a mixing tank (A) to a disinfestation unit (B), the crop zone $(\mathrm{C})$ and the area with troughs in a parallel arrangement (D), and subsequently drains from the troughs into a collection pipe (E) in which the solution is returned to the mixing tank. The solution is recharged with water and nutrients in the tank, and may be treated in the disinfestation unit to destroy pathogen propagules, such as by heat pasteurization, filtration, or ultraviolet radiation. Plants are grown in the troughs, which may or may not contain a rooting medium such as rockwool or coconut fiber.

such as $P$. intermedium and $P$. irregulare $(82,101)$, have also been reported in hydroponically-grown plants. The genus Pythium belongs in the family Pythiaceae of the class Oomycetes, members of which were regarded as fungi for over a century and a half. However, Oomycetes are now commonly described as fungal-like and assigned to the Kingdom Straminipila (16).

\section{Sources of pythium inoculum in hydroponic crops}

The principal species of Pythium that attack hydroponic crops frequently occur in soils and plant residues in greenhouses and outdoors $(61,73,86)$. Inoculum of Pythium spp. can be introduced into greenhouses and hydroponic systems in many ways including airborne dust, in soil and plant fragments on greenhouse tools and equipment, on people's footwear, and in water used to prepare nutrient solution $(39,59,75,78,95,99)$. Pythium spp. were reported also in peat brought into greenhouses for use in rooting media $(23,87)$.

In Canada, transplants are a common source of Pythium in hydroponic vegetable crops. Some hydroponic vegetable growers produce their own transplants, but a majority obtain them from specialist producers who supply the plants in rockwool cubes. Growers who produce their own transplants often do so on benches in greenhouses that are not otherwise used for crop production. In several instances $P$. aphanidermatum and $P$. dissotocum were easily recovered from soil trapped in benches used for growing transplants, and the pathogens were frequent in roots of cucumber, pepper, and tomato transplants (W. Liu \& J.C. Sutton, 2000-2003, unpublished). Specialists generally begin production of transplants in rockwool plugs (about $2.5 \times 2.5 \times 4.0 \mathrm{~cm}$ ) contained in plastic trays, and subsequently transfer them to rockwool cubes (about $10.0 \times 10.0 \times 6.5 \mathrm{~cm}$ ) positioned in rows on laser-levelled concrete floors. Every few hours the floors are flooded with nutrient solution and allowed to drain so as to keep the cubes moistened. In this type of ebb and flood system, the nutrient solution is pumped from tanks below ground level, through pipes beneath the floors, and out onto the floors before draining back into the tanks. Despite extraordinary sanitation measures, some plants produced in these systems were found to be infected with $P$. aphanidermatum and P. dissotocum (Sutton, J.C. \& W. Liu, 2002, unpublished). The presumed inoculum source was the underground plumbing, which possibly harbored oospores and mycelium. In many instances, infected transplants from various production systems were symptomless when ready for shipping to growers.

It is possible that transplants of hydroponic salad crops such as lettuce, arugula, and Nasturtium officinalis also become infected by Pythium prior to being set out in hydroponic systems. In Pará State, Brazil, transplants are often produced in cells of seedling flats containing various rooting media, and positioned on benches sheltered from rain, wind, and direct sunlight. Some growers utilize styrofoam trays floating on water in tanks. Infection of transplants by Pythium seems possible in these systems, however we are not aware of any reports to confirm or refute this.

Hydroponic materials used previously for crop production may frequently harbor Pythium. Some growers re-use rooting media such as slabs of rockwool or coconut fiber, without sterilization or other measures to destroy pathogens in the media. This practice allows carry-over of inoculum of various pathogens, including Pythium spp., to the subsequent crop. Pipes, tubing, tanks and other plumbing components of hydroponic systems are often potential sources of Pythium in successive crops, even when the systems are treated with disinfectants. In studies in small-scale hydroponic systems, the chemical sterilants Virkon (potassium monopersulfate; Pace Chemicals, Burnaby, Canada) and Chemprocide (didecyldimethyl ammonium chloride; Dispar Inc., Joliette, Canada) were only partially effective in destroying P. aphanidermatum (C.R. Sopher and J.C. Sutton, 2003, unpublished). Sodium hypochlorite was completely effective, but can corrode some components of hydroponic systems. Oospores of Pythium spp. can frequently be found in biofilms, mucilaginous 
materials and root tissue fragments in hydroponic plumbing (C.R. Sopher and J.C. Sutton, 2003, unpublished) and are undoubtedly a principal form of inoculum. Oospores are also resistant to chemical sterilants. Oospore populations are also known to survive for months or years in field soils $(2,61,108)$.

Insect vectors are considered important means by which Pythium and other pathogens are introduced and dispersed in hydroponic crops. In North America, fungus gnats (Bradysia spp.) and shore flies (Scatella stagnalis Fallen.) were reported to acquire Pythium by external contamination or ingestion $(27,29,40)$. Pythium oospores were found in the digestive tracts of larvae and adults of each of these insects. In fungus gnats, oospores acquired during the larval stage remain in the digestive tract during pupation, and can be aerially transmitted generally in a viable state by the adults and eventually excreted in the frass (40). In Canada, fungus gnats are found wherever greenhouse crops are grown, and readily enter greenhouses through doors and ventilators (37). Their larvae feed on fungal mycelia and organic residues in soils, soilless mixes, hydroponic media, and nutrient solutions. The larvae are also known to feed on roots and root hairs of cucumbers and other plants, thereby making wounds through which pathogens may invade. It is likely that similar or different insects are factors in epidemics of root rot in hydroponic crops produced in warm temperate and tropical climates, but we have not encountered any reports on this possibility.

\section{Infection of roots by Pythium}

Pythium aphanidermatum, P. dissotocum, and Pythium group $\mathrm{F}$ infect roots of hydroponic plants by means of zoospores and mycelia $(21,73,82,86,99,122)$. The initial (primary) inoculum in root rot epidemics (that is, the inoculum which initiates the epidemics) is chiefly zoospores produced from sporangia formed by germinating oospores, or perhaps by mycelium (31), in plant residues, soil, hydroponic pipes and tubing, and other inoculum sources in the crop environment. Generations of zoospores arising from sporangia formed on infected roots of the hydroponic crop are a principal form of subsequent (or secondary) inoculum in root rot epidemics. Mycelia are the principal units of inoculum of P. ultimum var. ultimum, which produces few or no zoospores and is better adapted to conditions of greenhouse soils and soilless mixes than to systems with circulating nutrient solution (43). The reader is referred to Martin \& Loper (61) for details of $P$. ultimum var. ultimum.

Consistent with general acceptance by plant disease epidemiologists, the term infection is used here to refer to the process of establishment of a parasitic relationship of the pathogen in the host (9). In Pythium zoospores this process includes zoospore encystment at the root surface, synthesis of a thick cell wall, adhesion to the root surface, germination and germ tube growth, penetration of the root surface, and sufficient post-penetration development to allow the newly-formed colony to function independently of the germinated spore (33). Zoospores of $P$. aphanidermatum and other Pythium spp. were reported to penetrate non-wounded surfaces of all portions of young roots, including root cap cells, root hairs, and regions of meristematic activity, cell elongation, and cell maturation (21, 48, 56, 118). In general, however, root tips, elongation zones, and young root hairs are frequently penetrated. Pythium aphanidermatum and other Pythium spp. have been reported to penetrate roots directly by means of penetration pegs, fine hyphae, and enzymatic action (21, 28). Formal descriptions of P. aphanidermatum and P. dissotocum include appressoria (112), and indeed some authors observed appressoria or appressoria-like structures on roots by means of transmission or scanning electron microscopy $(15,21,86)$. In other studies, however, scanning electron microscopy did not reveal appressoria (28) or appressoria were not mentioned (21). Production of appressoria is known to vary with temperature and $\mathrm{pH}(21)$, and it is possible that incidence and density of appressoria during epidemics of Pythium root rot in hydroponic crops is highly variable. Besides direct penetration of roots, $P$. aphanidermatum and other Pythium spp. are able to infect wounded tissues, such as sites of emergence of lateral roots and sites of attack by larvae of fungus gnats.

Findings in several studies indicate that root mucilage on surfaces of roots and in surrounding nutrient solution is an important factor influencing infection of roots by Pythium hyphae, and in promoting Pythium populations in the root zone. Pythium group F, P. ultimum var. ultimum, and other Pythium spp. penetrate roots in zones of increased mucilage production such as junctions of cortical cells, zones of elongation, and at the base of lateral roots and root hairs $(43,67,86$, 118). Cucumber plants often produce abundant root mucilage that accumulates in the nutrient solution. Zheng et al. (122) reported on the role of this mucilage in epidemics of root rot caused by $P$. aphanidermatum. They found that the pathogen was more frequent in roots with associated mucilage than in those lacking mucilage, and that the amounts of mucilage correlated positively with root browning. These findings, combined with microscopic observations of Pythium hyphae in mucilage and roots, indicated that the mucilage supported prolific growth of $P$. aphanidermatum and served as a food base from which hyphae of the pathogen were able to invade the roots, including old roots which zoospores normally do not infect.

\section{Colonization and symptom development}

Colonization of plants by $P$. aphanidermatum and $P$. dissotocum in hydroponic plants is normally biotrophic in initial stages and subsequently necrotrophic (73). In the biotrophic phase the roots are colonized without development of overt symptoms, a condition sometimes referred to as subclinical (98). In the necrotrophic phase, the roots become discolored, generally as a hue of brown, grey-brown, reddish-brown, yellow-brown, or yellow, depending on the type of host and species or isolate of the pathogen. Pythium group F was found to colonize roots of hydroponic tomato plants without inducing visible symptoms under optimal conditions for plant growth, but some strains caused severe necrosis especially in stressed plants $(14,85,86)$.

Root colonization by $P$. aphanidermatum, $P$. dissotocum, and Pythium group F is both intercellular and intracellular $(21,71,85,98)$. Haustoria-like structures were reported in cells of spinach and pepper roots infected by $P$. dissotocum $(71,98)$. P. aphanidermatum normally colonizes the cortex of pepper roots (73), while $P$. dissotocum has been found in the stele of immature root tips of strawberry (69) and tends to colonize epidermal cells of roots (21). Each of these pathogens increased cytoplasmic granulation in cortical tissues of pepper (73). Pythium group F was found to colonize the epidermis and outer cortex of tomato roots, inducing marked disorganization of the host cells in a phase of pathogenesis interpreted as necrotrophy, and to subsequently ingress to the inner cortex and stele, where it induced various kinds of host defense reactions (85).

The necrotrophic phase of Pythium root rot in hydroponic pepper plants is marked by root tip browning and expansive browning $(P$. aphanidermatum) or yellowing (P. dissotocum) of the roots $(71,73)$. All isolates of $P$. aphanidermatum and $P$. dissotocum also produced 
architectural changes in the root systems, chiefly stunting, stubbiness, and root proliferation (73). Some isolates of $P$. dissotocum produced swelling of roots and proliferation of callus cells. Similar kinds of symptoms were found in hydroponically-grown chrysanthemums (58), lettuce, antirrhinums, (J.C. Sutton, W. Liu, M. Johnstone, and N. Ortiz-Uribe, 2002-2003, unpublished observations). In all hosts, roots were colonized by the Pythium isolates well in advance of expansive root browning or yellowing, such that much more root was colonized than exhibited overt symptoms as illustrated for chrysanthemum (Fig. 3). Thus, in agreement with comments of Kamoun et al. (52), root necrosis did not represent a hypersensitive reaction or incompatible response in which the host cells are quickly killed and advance of the pathogen is blocked.

Root browning is a susceptible necrosis reaction that develops in root tissues after they are infected and colonized by $P$. aphanidermatum and other Pythium spp. Browning is associated with accumulation of phenolic polymers, which in part may become bound to cell walls of root tissues $(20,72)$. In recent studies, concentrations of bound phenolics, which include simple as well as polymerized forms, greatly increased in pepper roots inoculated with $P$. aphanidermatum, but remained low in noninoculated controls $(72,103)$. Concentrations of free phenolics, however, increased only slightly in inoculated roots and were similar to those in noninoculated roots. While it is possible that synthesis of free phenolics did not increase in inoculated roots, it is more likely that synthesis did increase but that concentrations in the roots remained low because of systemic transport to other parts of the host or release into the nutrient solution, as was found in hydroponic lettuce (11). Most phenolics in higher plants are derived at least in part from phenylalanine, a product of the shikimic acid pathway. Deamination (release of ammonia) from phenylalanine by phenylalanine ammonia lyase (PAL) yields trans-cinnamic acid, derivatives of which are simple phenolic compounds called phenylpropanoids, important building blocks of more complex phenolic compounds (105). Elicitors of P. aphanidermatum and other pathogens are known to increase PAL in cultured plant cells and protoplasts (91). Collectively, the available evidence indicates that $P$. aphanidermatum and other Pythium spp. markedly activate the

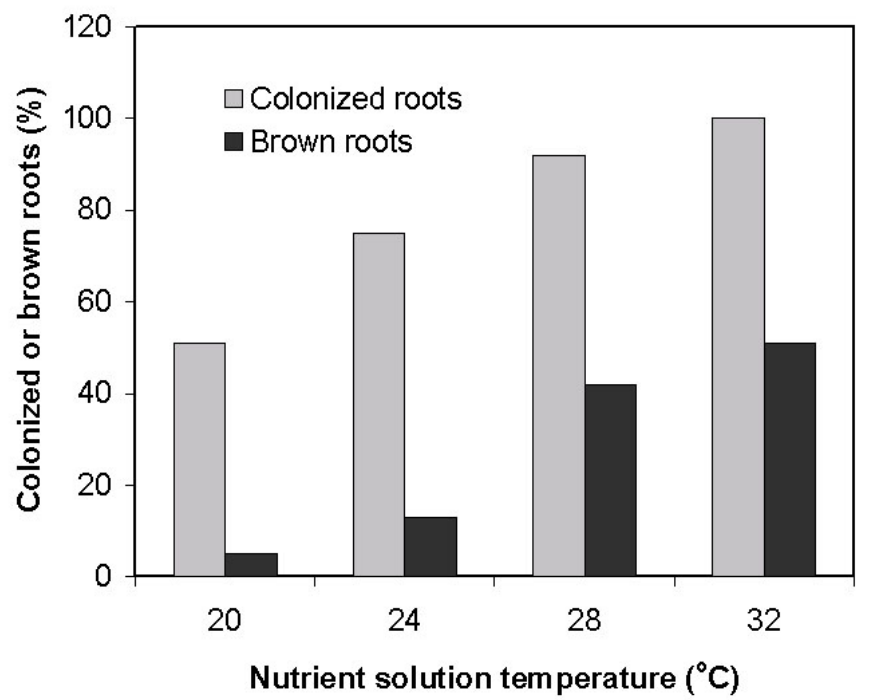

Figure 3. Effects of temperature of the nutrient solution on colonization of chrysanthemum roots by Pythium aphanidermatum and associated root browning at 14 days after the roots were inoculated with the pathogen. shikimic acid and phenylpropanoid pathways, and promote biosynthesis of phenolic compounds in infected roots.

Recent findings point to the exciting possibility that Pythium aphanidermatum triggers necrosis in host roots by means of a specific elicitor. Veit et al. (113) sequenced a secondary metabolite of the pathogen, and determined its ability to induce cell death in carrot, Arabidopsis, and tobacco. The metabolite, called the $P$. aphanidermatum necrosis-inducing elicitor or $\mathrm{PaNie}$, has a high degree of sequence similarity with necrosis-inducing elicitors of Phytophthora spp. and Fusarium oxysporum $(3,24,81)$. Evidence indicates that PaNie induces the phenylpropanoid pathway in the host (91).

Symptoms on aerial portions of crops affected by Pythium root rot often include stunted shoots, wilted leaves, and smaller, fewer fruits $(71,122)$. The leaf canopy of sweet pepper, cucumber, and several other hosts normally remains green until root rot is extremely severe such that many roots are brown, decayed and fragmenting. Moreover, in our experience, leaves of pepper plants inoculated with $P$. aphanidermatum or $P$. dissotocum within a few days often appear darker green than those of noninoculated control plants. Foliage of commercial crops with severe root rot often appears in good health except that it is typically stunted. Canopy stunting may go unnoticed for a considerable time because all plants in the cohort are similarly affected $(71,98)$. Pythium root rot stunts shoot growth and reduces flowering and fruiting long before the foliage wilts or becomes chlorotic. Wilting is initially temporary, often in association with high daytime temperatures, but in many instances becomes permanent. Under some conditions, severely-affected peppers and certain other kinds of hydroponic crops are able to regenerate roots sufficiently to sustain green foliage for long periods, but growth and productivity normally are reduced or poor.

\section{Inoculum production}

Pythium aphanidermatum, $P$. dissotocum and Pythium group $\mathrm{F}$ produce abundant sporangia, zoospores, and oospores in association with roots of hydroponic crops. Sporangia are generally formed on mycelium at or near the root surface (86). Sporangia of $P$. aphanidermatum have been encountered also in association with mycelia in cucumber root exudates floating in the plant nutrient solution (122). In field soils, lobate sporangia such as those of $P$. aphanidermatum may survive only a day or two, and are exogenously dormant on account of microbiostasis $(61,96,97)$. The survival of sporangia and their ability to produce zoospores in root zones of hydroponic crops is not well-understood. However, zoospores can be found in nutrient solutions during most phases of root rot epidemics, though are sometimes difficult to detect $(53,66,71,100)$. The majority of zoospores probably arise from sporangia on mycelium while some may form from sporangia formed from germinated oospores (97). As in all Pythium spp., the zoospores are not formed in the sporangium itself but in a vesicle outside it (112).

Oospores of P. aphanidermatum, P. dissotocum, and Pythium group $F$ form in infected roots, especially in cortical tissues, and can be found on mycelia in nutrient solution surrounding the roots and rooting media, such as among slivers of rockwool. In investigations of hydroponic peppers inoculated with $P$. aphanidermatum or $P$. dissotocum, oospores were less numerous in discoloured (brown) portions of roots than in portions that were not discoloured (73). Density of oospores in the roots varied markedly with pathogen isolate. Oospores are the principal survival structures of Pythium spp. (61), but quantitative aspects of oospore survival in hydroponic 
systems remain to be explored. Based on observations of $P$. aphanidermatum and other Pythium species in soils and host residues (61), oospores may survive for at least several months in fragments of dead roots or in a free state in troughs, used rooting media, and plumbing components of hydroponic systems. Oospores exhibit constitutive dormancy, so that some of them do not germinate even under conditions conducive to the germination of mature oospores (61). Temperature, $\mathrm{pH}$, age, and other variables influence the conversion of dormant to germinable oospores (1). Germination frequency of $P$. aphanidermatum oospores from culture was found to be initially low (27\%) and progressively increased after 1 to 2 weeks (2), whereas only $10 \%$ of those produced in soil were capable of germination (108).

Hyphae are a further form of Pythium inoculum of potential importance in root rot epidemics. Hyphal fragments of $P$. aphanidermatum and $P$. dissotocum recovered from nutrient solution in root zones of peppers grown in small-scale trough systems were, in most instances, associated with fragments of rotted roots (A. Khan, N. Owen-Going \& J.C. Sutton, unpublished). However, dissociated hyphae are easily overlooked. Growth of hyphae of $P$. aphanidermatum from slimy masses of root exudates in the nutrient solution to roots of cucumbers was reported in trough systems (122). The role of hyphae in plant to plant spread of $P$. aphanidermatum was demonstrated in cucumbers grown in rockwool slabs with recirculating nutrient solution amended with a nonionic surfactant to inactivate zoospores (100).

\section{Inoculum dispersal}

Circulating nutrient solution is a principal means by which propagules of Pythium are dispersed in hydroponic crops. Patterns and rates of dispersal of Pythium propagules can be expected to vary in relation to the type of propagule, pattern and dynamics of flow of the nutrient solution, and impediments in flow paths such as roots, rooting media, and physical components and structure of the hydroponic system. Motion of nutrient solution through root zones in hydroponic troughs with no rooting medium (the socalled nutrient-film technique or NFT) include zones of rapid streaming between root masses and zones of slow movement or stagnation in areas occupied by roots (36). The latter increase proportionately as root systems grow. Roots, rooting media, and plumbing components in various kinds of hydroponic systems provide large surface areas on which propagules are potentially deposited or trapped. Movement of nutrient solution through collecting pipes and in mixing tanks is generally rapid and turbulent. The physical structure of the hydroponic system may markedly influence propagule dispersal. For example, when nutrient solution is fed to individual slabs of rockwool compartmentalized in plastic film and recirculated from the slabs through pipes and mixing tanks, propagules have the immediate possibility of dispersal only among the few plants, often two to six, growing in any particular slab (Fig. 1). This contrasts with troughs that each accommodate numerous, often hundreds, of plants, and which thus favor immediate downstream dispersal of propagules to many plants within the trough (Fig. 2).

Zoospores of Pythium and other Pythiaceous microbes are dispersed by transport in nutrient solution $(36,77,99,100)$ and are also motile by means of two flagella $(17,33)$. Zoospores of Phytophthora spp. were found to be dispersed only short distances $(<10 \mathrm{~cm})$ in stagnant or standing water, but comparatively long distances in flowing water (36). In hydroponic troughs in which root systems are well-developed, zoospore populations tend to be high and aggregated in zones of slow movement of nutrient solution, and zoospore dispersal is largely localized among nearby roots $(36,84)$. These findings, and perhaps intuition, suggest that localized dispersal of Pythium and Phytophthora zoospores may predominate in roots grown in rockwool and other media where movement of nutrient solution is slow. However, there is abundant evidence, though largely circumstantial, that portions of zoospore populations are dispersed rapidly throughout major portions of small- and commercial-scale hydroponic systems $(53,65,66,71$, 98 ). When flow of the nutrient solution is turbulent, zoospores abruptly shed their flagella and encyst, thereby losing the necessary ability for chemotaxis towards potential infection sites on roots. Even minor movement and vibration of zoospore suspensions, such as in glassware on a moving laboratory cart, can trigger shedding of flagella. Observations in commercial crops of sweet pepper grown in troughs without a rooting medium indicated that few zoospores or other Pythium propagules returned to the crop in nutrient solution that was recirculated through pipes and mixing tanks (71). About 10 to 55 zoospores $\mathrm{mL}^{-1}$ nutrient solution were found at outflows of the troughs, but d" 0.1 zoospores $\mathrm{mL}^{-1}$ solution were recovered, all encysted, before the nutrient solution flowed into the mixing tank, and none usually was found after the mixing tank. Zoospores probably were not recovered on account of deflagellation, lysis, encystment, sedimentation, adhesion to various surfaces, inactivation, and death.

Dispersal of oospores and hyphal fragments of Pythium in hydroponic nutrient solutions has been reported only incidentally $(39,71,100)$. It can be anticipated that these propagules are dispersed as free entities or in association with root fragments, especially during stages of epidemics when roots are rotting. Fragments of sloughed root cortices with oospores and hyphae of P. aphanidermatum were frequently observed in epidemics of root rot in small-scale trough systems (J.C. Sutton, A. Khan \& N. OwenGoing, 2002; unpublished). In contrast to oospores, hyphal fragments of Pythium spp. are short-lived in many environments (61), yet there remains the possibility that they may survive long enough to make contact and possibly infect other roots. Based on apparent circumstantial evidence from cucumbers in small-scale hydroponic systems, Stanghellini et al. (100) concluded that hyphal fragments either do not occur or do not function as effective inoculum for dissemination in recirculating nutrient solution.

Pythium propagules may be dispersed between troughs, or among slabs of rockwool or other rooting media by fungus gnats and shore flies (discussed above), splashing water, greenhouse equipment, and workers $(29,39,40,59)$. Water dripping from the greenhouse roof can often splash onto exposed rooting media, nutrient solutions, plants, and the greenhouse floor, thus affording the possibility of splash dispersal of Pythium propagules. Transmission of only a few propagules from trough to trough or slab to slab may allow Pythium to establish effectively in previously uncontaminated root zones (66). Several investigators have reported trough to trough transmission $(66,98$, $100,116)$, though the mode of transmission was usually not known. While dispersed zoospores may encyst and so become immobilized, the cysts are more resistant to extremes of temperature, desiccation, or ionic environment than are zoospores (33). However, their ability to adhere to roots and other surfaces decreases over time. 


\section{Epidemiology of root rot}

An understanding of root rot epidemics is fundamental to the development and refinement of methods and practices to manage the disease in hydroponic crops, but remains fragmentary. While root rot is almost universal in commercial hydroponic systems, and in many instances becomes sufficiently severe to cause serious crop losses, it is also true that in many other instances progress and spread of the disease is comparatively slow and losses are perceived as minor. From the literature, and an abundance of anecdotal evidence from greenhouse growers and crop advisory personnel, it is clear that a myriad of variables significantly influence Pythium species and root rot development in hydroponic systems. Important variables range from subtleties such as calcium in the root zone, which at millimolar levels strongly influence adhesion of zoospores to roots (33), to elevated temperature, which can bring about abrupt and explosive increases in root necrosis in large portions of crops $(4,28,39,54,61,83,107)$. This portion of the present article will now focus on effects of factors associated with the host, the pathogen, the environment of the nutrient solution and plant canopy, and human interferences on disease severity and pathogen ecology. Excellent perspectives of the general principles of epidemiology are given in Zadoks \& Schein (119) and Bergamin Filho \& Amorim (7). For a critical review of the epidemiology of diseases caused by Pythium spp. in plants grown in soil, attention is drawn to Martin \& Loper (61).

\section{Host Factors}

To our knowledge, all cultivars of all vegetables and flowers produced in greenhouse hydroponic systems in Canada, the USA, Brazil, France, and other countries are susceptible to moderate or severe epidemics of Pythium root rot. These crops include cucumbers, tomatoes, sweet peppers, lettuce, spinach, arugula, nasturtium, and roses. Other crops such as chrysanthemum and antirrhinum have not yet been widely successful in hydroponic systems in part on account of severe root rot. In Canada, casual observations and anecdotal reports indicate that tomatoes generally are less severely affected than are cucumbers and sweet peppers. We are not aware of any published reports of quantitative differences in cultivar susceptibility to root rot in various hydroponic crops, but in some instances growers consider that some cultivars of hydroponic vegetable crops are less susceptible than others. Kamoun et al. (52) reported differences in host susceptibility to Pythium root rot based on plant age and tissue development.

Susceptibility to Pythium root rot is normally reported in terms of the severity of browning (or other discoloration) and fragmentation of the roots, or as root growth parameters such as volume, length, fresh mass and dry mass. Estimation of symptoms, however, focuses only on the necrotrophic phase of disease and neglects susceptibility to the biotrophic phase including the infection process and colonization. In our experience, root systems of peppers and chrysanthemums inoculated with $P$. aphanidermatum or $P$. dissotocum in small-scale hydroponic units under some conditions were symptomless yet heavily colonized by the pathogen. Other investigators reported similar findings with $P$. dissotocum and Pythium group F $(86,98)$. Further, we have frequently noted that a large proportion of colonized but symptomless roots (e.g. 30-70\%) turn brown during a short interval (e.g. 12 to $24 \mathrm{~h}$ ) between observations. Critical assessment of susceptibility requires estimation of infection frequency and colonization in inoculum dose-response studies, as well as estimation of symptoms. Environmental conditions need to be critically controlled in view of the sensitivity of colonized roots to the transition from biotrophy to necrotrophy.

Phenological growth stage and age of roots influence root rot severity in hydroponic crops but quantitative relationships of these variables and rates of disease increase are not well-understood. Root browning and rotting often progress for almost the entire life of the crop, which in Canada is about 4 months for cucumbers, 10 to 11 months for tomatoes, and 10 to 18 months for sweet peppers. Each of these hosts has an extraordinary ability to continually produce new roots, which frequently become attacked by Pythium. In general, zoospores of $P$. aphanidermatum, $P$. dissotocum, and Pythium group F, as well as other Pythium species, infect young roots regardless of the phenological growth stage of the host, but do not infect older roots $(33,61,89)$. However, Zheng et al. (122) found that hyphae of $P$. aphanidermatum growing from root mucilage in the nutrient solution invaded young and old cucumber roots. In this study, root growth, quantities of root mucilage, and percent discolored roots oscillated in patterns that were similar and synchronous, which suggested that the dynamics of root growth and mucilage accumulation are fundamental factors contributing to patterns of root browning and rot associated with $P$. aphanidermatum. Root mucilage is readily utilized by rhizosphere bacteria (55), including microbial agents that, by destroying the mucilage, may restrict saprophytic development of $P$. aphanidermatum and its ability to attack roots via hyphae (122). In general, qualitative and quantitative shifts in mucilage and other exudates from roots at various stages of crop development appear to markedly affect root zone microbes including Pythium spp., which depend on exogenous nutrients for germination and infection (61).

Recent studies in our laboratory have demonstrated for the first time that environmental stress factors can increase the susceptibility of hydroponically-grown plants to Pythium root rot. The studies were conducted using pepper plants in singleplant hydroponic units with aerated nutrient solution. When temperature of the nutrient solution was raised to $28^{\circ} \mathrm{C}$ or $34^{\circ} \mathrm{C}$ for a few hours or days and subsequently lowered to 22 $24^{\circ} \mathrm{C}$ prior to inoculation of the root systems with $P$. aphanidermatum, root browning progressed earlier and more rapidly than in control plants maintained at $22-24^{\circ} \mathrm{C}$ before inoculation (C.R. Sopher \& J.C. Sutton, unpublished). Similarly, when plants were kept in nutrient solution ( $\mathrm{pH} 5.8)$ amended with certain simple phenolic compounds for $48 \mathrm{~h}$ and then placed in unamended solution for $24 \mathrm{~h}$ before inoculation with $P$. aphanidermatum, disease severity increased more rapidly than in untreated controls (103). This finding suggested that phenolics escaping from diseased roots might predispose downstream healthy plants to attack by Pythium. Collectively, the studies demonstrated that high temperature and phenolic compounds predisposed the plants to root rot. By definition, predisposition refers to increased susceptibility of plants to disease brought about by environmental factors acting prior to infection by the pathogen (39). It is likely that other environmental stressors or stress conditions, such as low intensity light and low concentration of dissolved oxygen in the nutrient solution also predispose plants to Pythium root rot. Chérif et al. (14) found that Pythium F colonized roots of hydroponically-grown tomatoes more extensively when concentration of dissolved oxygen was moderate (5.8-7.0\%) or low $(0.8-1.5 \%)$, than at high levels $(11-14 \%)$, however, it was not determined whether the influence of reduced oxygen was through increasing susceptibility of the host, or through effects on the pathogen or the host-pathogen interaction. 


\section{Pathogen Factors}

Substantial intraspecific variation in pathogenicity and virulence exists in species of Pythium that attack hydroponic crops. Symptoms produced by isolates of $P$. dissotocum in pepper varied widely but generally overlapped with those caused by other isolates, and included zones of root-tip browning of different sizes and hues, different severity of expansive root yellowing, architectural changes, root swelling, and callus cell proliferation (73). Isolates of $P$. aphanidermatum usually are highly virulent in hydroponic crops, but variation in virulence was reported in tomato (32) and among twelve plant species grown in soil (63). Rafin \& Tirilly (82) reported that isolates of Pythium group $\mathrm{F}$ variously caused localized necrosis at root apices and more severe and progressive root rot. In view of the intraspecific variation in $P$. aphanidermatum and $P$. dissotocum, the variation in Pythium spp. grouped as Pythium $\mathrm{F}$, and the environmental sensitivity of symptom expression by various Pythium strains, it is probable that the composition of Pythium species and strains in a given crop can markedly influence patterns of root rot epidemics $(71,73)$.

\section{Environmental and Microbial Factors}

Development of severe root browning and root rot in hydroponic crops produced in greenhouses in Canada often coincides with hot weather when temperature of the nutrient solutions and of the greenhouse in general is high. Some growers have replenished the nutrient solution with fresh solution prepared with cool water from wells to help alleviate the problem. Pythium aphanidermatum is widely known to cause severe symptoms of root rot in various crops when root zone temperature is moderate or high $\left(\mathrm{e}^{\prime \prime} 23-27^{\circ} \mathrm{C}\right)(4,28$, $61,73,107)$. In chrysanthemums grown in single-plant containers with controlled root-zone temperature, the pathogen caused progressively more severe root rot symptoms with increase in temperature from $20^{\circ} \mathrm{C}$ to $32^{\circ} \mathrm{C}$ (Fig. 3). In a parallel study, progress curves for root discoloration caused by $P$. dissotocum were similar at $24-32^{\circ} \mathrm{C}$, but lower at $20^{\circ} \mathrm{C}$. Root disease caused by $P$. dissotocum in spinach was reported to be severe at $21-27^{\circ} \mathrm{C}$ but even more severe in winter months when nutrient solution temperatures were low (28). Fortnum et al. (26) found that root necrosis caused by P. myriotylum in tobacco seedlings in a greenhouse float system was lowest when the nutrient solution temperature was $15^{\circ} \mathrm{C}$ and highest at $30^{\circ} \mathrm{C}$. It is important to recognize that effects of temperature on symptom development can differ markedly from those when the pathogen colonizes the tissues symptomlessly during the biotrophic phase. In our experience, roots of hydroponic peppers and chrysanthemums can be extensively colonized by $P$. aphanidermatum or $P$. dissotocum but remain almost symptomless at 16 to $18^{\circ} \mathrm{C}$, yet develop severe symptoms within minutes or hours when the temperature is raised to $24-28^{\circ} \mathrm{C}$ (N. Owen-Going, W. Liu \& J.C. Sutton, unpublished). Temperature also differentially affects other stages of Pythium infection cycles such as the production, dispersal and germination of zoospores, oospore germination, and infection processes (61). The progress curves of root browning represent integrated effects, both direct and indirect, of temperature on the pathogens and their interactions with the roots.

Concentration of dissolved oxygen in the nutrient solution is a critical factor influencing root rot and crop productivity $(14,38,88$, 120). In general, root rot increases when oxygen levels are low (14). Gases move to and from roots of plants in many types of hydroponic systems chiefly by mass flow of gas dissolved in moving solution, which contrasts with diffusion through gas-filled pores as occurs in soils. Oxygen concentration in the root zone of hydroponic crops is commonly 6 to $8 \%$ (123) and growers have been encouraged to maintain a minimum of $5 \mathrm{mg}$ oxygen $\mathrm{L}^{-1}$ nutrient solution (36). Concentration of dissolved oxygen can quickly decline, however, especially when temperature of the nutrient solution is high. In the absence of biological factors, the level of dissolved oxygen in water declines, for example, from about 9 to $7 \mathrm{mgL}^{-1}$ as temperature increases from 20 to $35^{\circ} \mathrm{C}$ at $101.3 \mathrm{kPa}$ and $100 \%$ relative humidity. Of greater importance, however, is greatly increased demand for oxygen by roots and rootzone microbes as temperature increases, factors that become particularly important when crops have produced dense masses of roots and when microbial populations are high. It has been further estimated that a crop that is environmentally stressed requires about ten times more oxygen than one not under stress $(39,94)$. While allowing the nutrient solution to free fall back into the nutrient recharge tank helps to maintain adequate oxygen levels, injection of oxygen directly into the solution may be needed, especially in continuously recirculating systems. Oxygenation is one of the few practical measures available to growers when root rot is well advanced, and helps to avoid further necrosis, disintegration, and sliminess of the roots (39). The observations of Chérif et al. (14) suggest that elevated levels (e.g. 11-14\%) of oxygen would be advantageous in protecting roots and promoting crop productivity.

Recirculation of nutrient solution in greenhouse hydroponic systems increases the risk of accumulation of phenolic and other organic acids to phytotoxic levels in the root zone $(49,50,51,114)$. These organic compounds are excreted as root exudates and by rhizosphere microbes, and are also released by constituent devices in the growing system $(114,117)$. Concentrations of total phenolic compounds of 23-30 $\mu \mathrm{g}$ gallic acid equivalents per litre of nutrient solution were found in root zones of 6-month-old hydroponic pepper crops in Ontario (T.N. Owen-Going and J.C. Sutton, 2004, unpublished observations). Phenolic compounds commonly associated with roots and nutrient solution of tomatoes and peppers, for example, include benzoic, caffeic, chlorogenic, ferulic, $p$-hydroxybenzoic, salicylic, and vanillic acids, most of which produce phytotoxic effects at 200 to 400 $\mu \mathrm{M}$ in the nutrient solution $(10,49,72)$. Rhizosphere microbes can utilize phenolic acids $(8,115)$, and the rate of utilization is substantially affected by oxygen concentration (74). Thus, microbes can potentially ameliorate the toxicity of phenolic compounds to hydroponic crops (11). Recent studies of hydroponic peppers in our laboratory demonstrated that several phenolic acids applied in the nutrient solution at a final concentration of $200 \mu \mathrm{M}$ exhibited allelopathic effects, but concentrations of 2 to $200 \mu \mathrm{M}$ also predisposed the plants to root rot caused by $P$. aphanidermatum $(72,103)$. In this system allelopathic phenolics rapidly increased in roots infected by $P$. aphanidermatum, promoted sporangia production by the pathogen, leaked into the nutrient solution, exhibited toxicity to pepper, and predisposed pepper to attack by the pathogen. Based on these findings, it was hypothesized that $P$. aphanidermatum, by increasing phenolics in roots, initiates autocatalytic cycles of events that accelerate root rot epidemics and health decline in peppers (103).

Hydroponic systems are often extraordinarily conducive to root rot epidemics in part because the root zones lack communities of microbes that can effectively antagonize pathogenic species of Pythium associated with the roots, rooting media, and nutrient solution. In contrast to microbial communities in natural soils, microbial diversity and density in hydroponic systems are frequently low. A majority of hydroponic crops are germinated (or otherwise propagated), and subsequently transplanted, in hydroponic units with rooting 
media, nutrient solution, and components such as plastic containers, troughs, and tubes that contain comparatively few microbial propagules. It can be anticipated that, during crop development, further incidental microbes enter the root zone, and that the density and diversity of microbial communities increases as availability and diversity of food sources from rhizodeposition increase, but published data to support this are sparse. In cucumbers transplanted into small-scale hydroponic trough units with recirculating nutrient solution, estimated density of fungal propagules was initially about $10^{2}$ colony forming units $(\mathrm{cfu}) / \mathrm{mL}$, increased to near $10^{4} \mathrm{cfu} /$ $\mathrm{mL}$ by day 53 , and remained near this value until the study ended on day 102 (122). Bacterial density increased from slightly below $10^{5} \mathrm{cfu} / \mathrm{mL}$ to peaks of $10^{8}-10^{9} \mathrm{cfu} / \mathrm{mL}$ at 74 and 95 days. Propagule density of Pythium, Penicillium, Fusarium, other fungi, and bacteria was, in most cases, one hundred to one thousand times greater in the root mucilage than in adjacent nutrient solution. Patterns of increase in density of bacterial and fungal propagules in the nutrient solution were also reported for rockwool-grown tomatoes at about 4 to 6 months after transplanting (109).

While buildup of root-zone microflora during the life of a hydroponic crop can be substantial, sanitation practices and use of new plastic materials and rooting media preclude all but minor carryover of microflora into the subsequent crop. Thus, the very practices that aim to eliminate pathogens also remove microbes that potentially antagonize pathogens, which again contrast with crops grown in natural soils. However, some hydroponic cucumber growers in Ontario, Canada, boldly reused rockwool slabs for up to four successive crops and found that root rot was always less severe in the used slabs than in crops where new slabs were used. These anecdotal reports were consistent with recent scientific findings that the microflora of used rockwool plays an important role in suppressing root and crown rot symptoms caused by $P$. aphanidermatum in cucumber (79). These investigators also found that suppressiveness was easily transferable between water-saturated rockwool slabs, and was associated with differences in structure of bacterial populations as visualized by using polymerase chain reaction (PCR) followed by denaturing gradient gel electrophoresis (DGGE). Despite the suppressiveness of used rockwool, it would be inappropriate to advise growers to reuse rockwool slabs on account of the potential presence of other pathogens and pests. Subsequent investigations of the rhizosphere microflora in cucumbers grown in used rockwool revealed that fast-growing bacteria predominated at the root tips, whereas slow growing bacteria were most abundant at root bases (25). Further, the proportion of fast-growing bacteria decreased as plants developed through vegetative and reproductive stages, even on root tips, which are young tissues regardless of plant phenological growth stage. DNA microarray technology, combined with PCRDGGE and conventional colony counts on agar media, should allow critical characterization, profiling, and tracking of root zone microflora and their relationships to pathogen suppression.

General experience in the greenhouse industry indicates that the type and structure of hydroponic systems greatly influence severity of root rot epidemics in hydroponic crops. In Canada, reports of severe epidemics are more frequent for crops grown in trough systems, in which the nutrient solution circulates among roots of scores, hundreds, or thousands of plants before returning to the mixing tank, than in highly compartmentalized systems such as rockwool slabs in which only a few plants share a common root zone. The industry findings are consistent with expected patterns of pathogen dispersal, especially zoospores, in relation to compartmentalization of root zones.
Risk of severe root rot is also considered higher in systems with continuously recirculating nutrient solution ("closed systems") compared to those where the solutions are allowed to run to waste ("open systems") $(42,64)$. However, in a study of tomatoes grown in rockwool, incidence of colonization of roots by Pythium was higher in an open system than in a closed system (109). In container-grown crops, which generally are ornamentals such as gerberas and roses, root rot is normally more severe when the containers are positioned on the bottom of wide-based troughs through which nutrient solution is allowed to flow, as opposed to when the containers are elevated well above the troughs and the plants are fed entirely through capillary tubes positioned in the rooting medium. Effects of the presence and type of rooting medium on root rot epidemics in commercial hydroponic systems are not well-understood. In Ontario, Canada, root rot epidemics in pepper and tomato have tended to be severe when crops were grown in trough systems with rockwool or with no rooting medium. Some growers reported fewer root rot problems when they used coconut fiber or certain grades of peat as opposed to rockwool. When containers are used in hydroponic systems it would probably be advantageous to use pathogen-suppressive rooting media $(34,35)$.

\section{Human Interferences}

Numerous practices used to produce and protect hydroponic crops influence the incidence and patterns of increase and spread of root rot epidemics. It is outside the scope of this article to review what is known of these practices in relation to root rot, however principal measures that are used, or that have potential use against root rot in various kinds of hydroponic systems are summarized in Table 1. Further details are available in the following publications: Bélanger \& Menzies (5); Bélanger et al. (6); Chatterton et al. (12); Chérif \& Bélanger (13); Ehret et al. (18); Evans (22); Folman et al. (25); Jarvis (39); Jensen \& Collins (42); Jung (49); Khan et al. (53); Lopes (59); Lopes et al. (60); Menzies \& Bélanger (65); Paulitz (75); Paulitz \& Bélanger (76); Punja \& Yip (80); Runia (90); Schuerger (93); Sutton et al. (104); Utkhede et al. (110); Zheng et al. (122)

From the epidemiologic perspective, disease management practices can achieve two principal effects $(7,119)$. First, they can reduce the level of initial (or primary) inoculum of the pathogen in the crop environment. This is the inoculum that can initiate the epidemic, analogous to a match lighting a fire. Secondly, they can reduce the rate of increase in severity of the epidemic, analogous to the rate at which the fire burns and spreads. In Table 1, practices that are thought to influence chiefly the initial inoculum of Pythium are distinguished from those that help to keep down the rate of increase of root rot after epidemics have begun (eg 19, 30). In Ontario, infected transplants, though often symptomless, frequently contribute to the initiation of root rot epidemics in crops. Thus root rot control should begin with the seed, cutting, and other propagative material.

Among the practices that aim to reduce rates of increase of root rot, it is important to distinguish the epidemic impact made by disinfesting the nutrient solution as it recirculates outside of the crop from that made by treatments that suppress Pythium in the roots and root zone of the crop (Table 1). In tomatoes (121) and in our investigations with lettuce and chrysanthemums in smallscale trough systems (18-20 plants per trough) with recirculating nutrient solution $(44,71)$ treatment of the solution with ultraviolet radiation (UV-C) at doses sufficient to kill Pythium propagules gave little or no suppression of root rot. Similar treatment in a commercialscale pepper crop in hydroponic troughs (NFT) did not significantly suppress root rot increase (102). These findings are not surprising 
Table 1. Practices for managing Pythium root rot in crops grown in hydroponic systems.

1. Practices to reduce levels of initial inoculum of Pythium.

- Sanitation measures to destroy or remove pathogen inoculum in sources within the greenhouse including crop residues, growing media, hardware components of the hydroponic system (containers, pots, pipes, tubing, troughs, etc.), interior parts of greenhouse structures (floors, walls, roofs, benches).

EXAMPLES: By use of steam (pressure cleaning), chemical sterilants, temporary acidification ( $\mathrm{pH} 2.0$ or 3.0) of nutrient solution, solarization during warm and sunny weather, fumigation.

-Measures to reduce or prevent introduction of inoculum into the greenhouse and hydroponic system.

EXAMPLES: Disinfestation of water used for nutrient solution, use of pathogen-free transplants and other plant materials, use of pathogen-free or sterilized planting media; use of screening on ventilators to exclude insect vectors; use of $1 \mathrm{~cm}$-deep layer of sterilized sand on top of rockwool cubes to prevent oviposition of fungus gnats; disinfestation of footwear; use of clean clothing and other personal hygiene; avoidance of a wide zone (example, $40 \mathrm{~m}$ wide) outside the greenhouse free from weeds and plant residues.

2. Practices to reduce rates of Pythium dispersal and root rot increase in the crop.

-Measures to disinfest the nutrient solution as it recirculates outside of the crop.

EXAMPLES: Heat pasteurization (such as $95^{\circ} \mathrm{C}$ for $30 \mathrm{~s}$ ), ultraviolet irradiation, ultrafiltration (membrane filtration), slow filtration (through sand, pumice, anthracite, or granulated rockwool), ultrasonic treatment, ozone treatment, activated hydrogen peroxide.

- Measures to suppress Pythium in the root zone of the crop.

EXAMPLES: Microbial agents, chemical pesticides (propamocarb hydrochloride [Previcur $\left.{ }^{\circledR N}\right]$, metalaxyl [Ridomil ${ }^{\circledR}$ ], electrolytically generated copper and cupric sulfate), oxygenation of the nutrient solution, soluble silicon, chitosan, surfactants, control of fungus gnats and shore flies, control of microclimate to minimize environmental stress factors (high temperature, low intensity light), use and orientation of greenhouse covering material (plastic film, glass) to minimize dripping of water from the roof into the crop.

given that most Pythium zoospores are dispersed locally among roots in the crop, and of those in effluent from troughs few survive the turbulent ride in nutrient solution through pipes and mixing tanks to the UV apparatus. Emphasis is needed on treating the root zone, such as with microbial agents, to protect the roots.

Several strains of specific microbes have been identified that have strong potential for controlling root rot in various kinds of hydroponic crops. They include Pseudomonas chlororaphis Tx1 (= Pseudomonas aureofaciens $\mathrm{Tx}-1)(12,53)$. Pseudomonas fluorescens 63-28 (58, 76) Comamonas acidovorans C-4-7-28 (58), Bacillus cereus HYU06 (58), Bacillus subtilis BACT-O (111), Gliocladium catenulatum J1446 (80), Lysobacter enzymogenes 3.1 T8 (25), and Clonostachys rosea (J.C. Sutton, 2003, unpublished observations). In our experience in commercial systems, biological control treatments should begin when plants are at the seedling or rooted-cutting stage, though good control is often possible in older plants in which disease has already begun to increase. Certain agents, such as $P$. chlororaphis, in some instances protect crops for several weeks or months without need for reapplication. Several of the microbes also appear to induce systemic resistance to powdery mildew and other foliage diseases (example: 122).

\section{Symptom development, growth of the shoots and crop productivity}

A surprising aspect of hydroponic crops with Pythium root rot is that the foliage often appears green and healthy even when root rot has become severe. Foliar discoloration normally develops only when the root systems have become almost entirely rotted. Under controlled conditions, the leaf canopy of pepper plants inoculated with $P$. aphanidermatum or $P$. dissotocum often becomes darker green than that of the noninoculated controls, which may indicate an important role of growth regulators in development of foliage symptoms.

The relationship of root disease caused by the various Pythium species and plant growth is currently understood chiefly from investigations in small-scale hydroponic systems. Reduced mass of roots and shoots, and reduced yield and quality of fruits or flowers were noted for several crops $(12,45,53,54,65,66,71$, $110)$. In pepper, $P$. aphanidermatum reduced the volume, fresh and dry mass, total length, and surface area of the roots, as well as total leaf area, and height, fresh mass and dry mass of the shoots over two to three weeks following inoculation $(53,72)$. In other experiments, concentrations of chlorophyll a, chlorophyll b, and total carotenoids expressed based on leaf area or fresh mass, were significantly higher in inoculated plants than in noninoculated controls (C.R. Sopher, 2003, unpublished).

The first characterization of alterations in whole-plant photosynthetic rate and carbon assimilation associated with Pythium infection of the roots was recently described in hydroponic peppers $(45,46,47)$. Inoculation of plants with $P$. aphanidermatum resulted in reduced whole-plant net carbon exchange rates (NCER), and a loss of $28 \%$ in cumulative carbon gain within 7 days. Leaf area, and dry weight of the shoots and roots, were significantly decreased, and the shoot:root ratio was higher in inoculated than in noninoculated plants. However, no differences were observed in NCER and evapotranspiration in inoculated compared to control plants when data were expressed based on leaf area and root dry mass, respectively. Thus Pythium infection did not appear to affect the photosynthetic apparatus directly, and the reductions in photosynthesis and growth were not caused by inefficient water transport by diseased roots. The main effect of root rot was to suppress the rate of increase in leaf area of the plants, as opposed to influencing the efficiency of photosynthesis per unit leaf area.

\section{Implications and possibilities for root rot management}

The knowledge and understanding of the etiology and epidemiology of Pythium root rot provides a valuable platform for rationalizing new research directions and developing better technologies and practices for managing root rot in hydroponic crops. Epidemiological information suggests that focus is needed in direct protection of roots 
against Pythium through treatments applied in the root zone, and that protection is needed beginning at the seedling stage and throughout a major portion of the crop cycle. Collectively, available data suggest that treatments that kill or inactivate Pythium in nutrient solution as it recirculates outside the crop are at best marginally effective in reducing the progress of root rot in large- and small-scale hydroponic systems. Such treatments may be important, however, for reducing the introduction of Pythium into hydroponic crops, and for destroying other pathogens, including viruses and bacteria.

Technologies to facilitate tracking of Pythium spp. and root disease are an obvious step in optimizing effectiveness of root-zone treatments such as use of microbial agents and oxygenation of the nutrient solution, as well as other measures to control root rot. Roots of hydroponic crops are generally out of sight and not easy to examine with any thoroughness, so that severity of root browning is difficult to determine. Further, visual examination does not detect infected roots that happen to be symptomless. Antibody-based dipsticks, other immunoassay-based diagnostic kits, and DNA microarrays that allow tracking of Pythium have already been developed $(57,62,77)$. Such assays have potential applications in standardizing the health of propagative materials, and to minimize the risk of introducing Pythium into hydroponic systems in, for example, the roots of transplants growing in rockwool cubes. They can also be used to detect or roughly quantify Pythium throughout later stages of crop development. Detection of Pythium does not necessarily imply that there is, or will be, a destructive epidemic of root rot. As summarized in previous sections of this article, development of severe root rot depends on numerous environmental and host factors, particularly high temperature and reduced levels of dissolved oxygen in the nutrient solution. A much better quantitative understanding of environmental variables in relation to root rot, and especially environmental stressors that predispose roots to Pythium attack, would open the doors for root rot prediction, and alerts for remedial action, driven by sensors in the canopy and nutrient solution. After decades of speculation, it is time to put some numbers on environmental stress conditions in relation to root rot. The recent findings that phenolic compounds accumulate in the nutrient solution, especially during root rot epidemics, and can threaten crop health directly and by predisposing plants to Pythium attack, signify a need for further investigations of phenolics, including any necessity for remediation of the solutions against phenolics. The new understanding of physiological responses of the plant canopy to root infection by Pythium (46) has paved the way for determining root disease severity by remote sensing in the canopy, and thereby avoiding the frustrations of examining roots directly.

Introduction of microbial agents, manipulation of the root zone microflora, oxygenation of the nutrient solution, and regulation of nutrient solution temperature are among the best available approaches to suppressing Pythium in the root zone, but each requires considerable investigation to provide practical and dependable know-how for growers. Much headway has been made in assessing effectiveness of microbes against Pythium in short-term experiments, but critical knowledge needed for long-term root protection throughout crop cycles, and in the face of shifts in the general microflora, chemical environment, and physical conditions in the root zone, is relatively sparse. Better understanding of the root-zone microflora in relation to Pythium, root rot, plant growth and disease resistance, root mucilages, allelopathic compounds of plant or microbial origin, and other key variables, should be possible with the aid of DNA microarray and other recent technologies to detect major microbial species and genes in the hydroponic system. Data banks of dissolved oxygen levels and temperature of the nutrient solution in relation to important variables such as Pythium, microbial agents, other microflora, root rot, and crop growth and productivity are needed to develop protocols for their rational use and to adequately understand the value of such use. Given the inadequate levels of host resistance to Pythium, new approaches to improve resistance such as through antibody-based mechanisms justify vigorous exploration. Fundamentally, new levels of integration of management practices against Pythium root rot and other diseases are needed that are appropriate to the kind of hydroponic system, whether sophisticated as in many greenhouses in Canada, the USA and some European countries, or simple yet functional like many of those in Brazil and other countries with warm climates.

\section{LITERATURE CITED}

1. Adams, P.B. Pythium aphanidermatum oospore germination is affected by time, temperature, and $\mathrm{pH}$. Phytopathology, Worcester, v.61, n.9, p.1149-1150, 1971.

2. Ayers, W.A.; Lumsden, R.D. Factors affecting production and germination of oospores of three Pythium species. Phytopathology, St. Paul, v.65, n.10, p.1094-1100, 1975.

3. Bailey, B.A. Purification of a protein from Fusarium oxysporum that induces ethylene and necrosis in leaves of Erythroxylum coca. Phytopathology, St. Paul, v.85, n.10, p.1250-1255, 1995.

4. Bates, M.; Stanghellini, M. Root rot of hydroponically-grown spinach caused by Pythium aphanidermatum and P. dissotocum. Plant Disease, St. Paul, v.68, n.11, p.989-991, 1984.

5. Bélanger, R.R.; Menzies, J.G. Use of silicon to control diseases in vegetable crops. Fitopatologia Brasileira, Brasilia, v.28 (Suplemento):S42-S45, 2003.

6. Bélanger, R.R.; Bowen, P.A.; Ehret, D.L.; Menzies, J.G. Soluble silicon: its role in crop and disease management of greenhouse crops. Plant Disease, St. Paul v.79, n.4, p.329-336, 1995.

7. Bergamin Filho, A.; Amorim, L. Doenças de Plantas Tropicais: Epidemiologia e Controle Econômico, São Paulo Editora Agronômica Ceres Lda, 1996. 289p.

8. Brune, A. Microbial degradation of aromatic compounds: aerobic versus anaerobic processes. Mitteilungen der Deutschen Bodenkundlichen Gesellschaft, Oldenburg, v.87, n.1, p.65-78, 1998.

9. Butt, D.J.; Royle, D.J. The importance of terms and definitions for a conceptually unified epidemiology. In: J. Palti; J. Kranz (Eds) Comparative Epidemiology. A Tool for Better Disease Management, Wageningen, Centre for Agricultural Publishing and Documentation, The Netherlands, p.29-45, 1980.

10. Candela, M.E.; Alcazar, M.D.; Espin, A.; Egea, C.; Almela, L. Soluble phenolic acids in Capsicum annuum stems infected with Phytophthora capsici. Plant Pathology, St. Paul, v.44, n.1, p.116123, 1995.

11. Caspersen, S.; Waechter, A.; Sundin, P.; Jensén, P. Bacterial amelioration of ferulic acid toxicity to hydroponically-grown lettuce (Lactuca sativa L.). Soil Biology Biochemistry, Oxford, v.32, n.8, p.1063-1070, 2000.

12. Chatterton, S.; Sutton, J.C.; Boland, G.J. Timing Pseudomonas chlororaphis applications to control Pythium aphanidermatum, Pythium dissotocum, and root rot in hydroponic peppers. Biological Control, San Diego, v.30, n.2 p.360- St. Louis, 3, 2004.

13. Chérif, M.; Bélanger, R.R. Use of potassium silicate amendments in recirculating nutrient solutions to suppress Pythium ultimum on long English cucumber. Plant Disease, St. Paul, v.76, n.10, p.10081011, 1992. 
14. Chérif, M.; Tirilly, Y.; Bélanger, R.R. Effect of oxygen concentration on plant growth, lipid peroxidation, and receptivity of tomato roots to Pythium F under hydroponic conditions. European Journal of Plant Pathology, The Netherlands, v.103, n.3, p.255-264, 1997.

15. Colt, W.M. Infection by Pythium aphanidermatum (Edson) Fitzp. as influenced by plant age and oxygen concentration. 1974. $134 \mathrm{p}$. Thesis (Doctorate) - University of California, Riverside, California.

16. Dick, M.W. Straminipilous Fungi. Dordrecht, the Netherlands, Kluwer Academic Press, 2000. 670 p.

17. Donaldson, S.P.; Deacon, J.W. Changes in motility of zoospores induced by calcium and calcium-modulating drugs. Mycological Research, London v.97, n.8, p.877-883, 1993.

18. Ehret, D.L.; Alsanius, B.; Wohanka, W.; Menzies, J.G.; Utkhede, R. Disinfestation of recirculating nutrient solutions in greenhouse horticulture. Agronomie, Versailles, v.21, p.323-339, 2001.

19. El Ghaouth, A.; Arul, J.; Grenier, N.; Benhamou, A.; Asselin, A.; Bélanger, R. Effect of chitosan on cucumber plants: suppression of Pythium aphanidermatum and induction of defense reactions. Phytopathology, St. Paul, v.84, n.3, p.313-320, 1994.

20. El Modafar, C.; Tantaoui, A.; El Boustani, E. Changes in cell wallbound phenolic compounds and lignin in roots of date palm cultivars differing in susceptibility to Fusarium oxysporum f.sp. albedinis. Journal of Phytopathology, Berlin, v.148, n.7, p.405-411, 2000.

21. Endo, R.M.; Colt, W.M. Anatomy, cytology and physiology of infection by Pythium. Proceedings of the American Phytopathological Society, St. Paul, v.1, p.215-223, 1974.

22. Evans, R.D. Control of microorganisms in flowing nutrient solution. Advances in Space Research, Oxford v.14, n.11, p.367-375, 1994.

23. Favrin, R.J.; Rahe, J.E.; Mauza, B. Pythium spp. associated with crown rot of cucumbers in British Columbia greenhouses. Plant Disease, St. Paul, v.72, n.8, p.683-687, 1988.

24. Fellbricht, G.; Romanski, A.; Varet, A.; Blume, R.; Brunner, F.; Englehardt, S.; Felix, G.; Kemmerling, B.; Krzymowska, M.; Nuernberger, T. NPPI, a Phytophthora-associated trigger of plant defense in parsley and Arabidopsis. Plant Journal, Oxford, v.32, n.3, p.375-390, 2002.

25. Folman, L.B.; Postma, J.; Van Veen, J.A. Ecophysiological characterization of rhizosphere bacterial communities at different root locations and plant developmental stages of cucumber grown on rockwool. Microbial Ecology, New York, v.42, n.4, p.586-597, 2001.

26. Fortnum, B.A.; Rideout, J.; Martin, S.B.; Gooden, D. Nutrient solution temperature affects Pythium root rot of tobacco in greenhouse float systems. Plant Disease, St. Louis, v.84, n.3, p.289294, 2000

27. Gardiner, R.B.; Jarvis, W.R.; Shipp, J.T. Ingestion of Pythium spp. by larvae of the fungus gnat, Bradysia impatiens (Diptera: Sciaridae). Annals of Applied Biology, Cambridge, v.116, p.205-212, 1990

28. Gold, S.E.; Stanghellini, M.E. Effects of temperature on Pythium root rot of spinach under hydroponic conditions. Phytopathology, St. Paul, v.75, n.3, p.333-337, 1985.

29. Goldberg, N.P.; Stanghellini, M.E. Ingestion-egestion and aerial transmission of Pythium aphanidermatum by shore flies (Ephydrinae: Scatella stagnalis). Phytopathology, St. Paul, v. 90, n.11, p.1244-1246, 1990.

30. Goldberg, N.P.; Stanghellini, M.E.; Rasmussen, S.L. Filtration as a method of controlling Pythium root rot of hydroponically grown cucumbers. Plant Disease, St. Louis, v. 76, n.8, p.777-779, 1992.

31. Green, H.; Jensen, D.F. Disease progression by active mycelial growth and biocontrol of Pythium ultimum var. ultimum studied using a rhizobox system. Phytopathology, St. Paul, v. 90, n.9, p.1049-1055, 2000.

32. Grover, R.K.; Dutt, S. Morphological and pathological variability in Pythium aphanidermatum. Indian Phytopathology, New Delhi, v.26, p.237-244, 1973.

33. Hardham, A.R. Cell biology of pathogenesis. Annual Review of Plant Physiology and Plant Molecular Biology. Palo Alto, v.43, p.491-526.

34. Hoitink, H.A.J.; Krause, M.S.; Han, D.Y. Spectrums and mechanisms of plant disease control with composts. In: Stoffella, P.J.; Khan, B.A. (Eds). Compost Utilization in Horticultural Cropping Systems, Lewis Publishers, Boca Raton, FL, USA, pp.263-273, 2001.

35. Hoitink, H.A.J.; Stone, A.G.; Han, D.Y. Suppression of plant diseases by composts. HortScience, Alexandria, v.32, n.1, p.184-187, 1997.

36. Holderness, M.; Pegg, G.F. Interactions of host stress and pathogen ecology of Phytophthora infection and symptom expression in nutrient-film grown tomatoes. In: Ayres, P.G.; Boddy, L. Boddy (Eds.). Water, Fungi, and Plants, Cambridge University Press, pp.189-205, 1986.

37. Howard, R.J.; Garland, J.A.; Seaman, W.L. (Editors). Diseases and pests of vegetable crops in Canada. The Canadian Phytopathological Society and the Entomological Society of Canada, p.554, 1994.

38. Jackson, M.B.; Blackwell, P.S.; Chrimes, J.R.; Sims, T.V. Poor aeration in NFT and a means for its improvement. J. Horticultural Science, London, v.59, n.3, p.439-448, 1984.

39. Jarvis, W.R. Managing diseases in greenhouse crops. American Phytopathological Society Press, St. Paul, MN, 1992.

40. Jarvis, W.R.; Shipp, J.L.; Gardiner, R.B. Transmission of Pythium aphanidermatum to greenhouse cucumbers by the fungus gnat Bradysia impatiens (Diptera: Sciaridae). Annals of Applied Biology, Cambridge, v.122, n.1, p.23-29, 1993.

41. Jenkins, D.G., Cook, K.L., Garland, J.L.; Board, K.F. Pythium invasion of plant-based life support systems: Biological control and sources. Life Support Biosphere Science, New York v. 7, n.2, p.209-218, 2000.

42. Jensen, M.H.; Collins, W.L. Hydroponic vegetable production. Horticultural Reviews, Westport v.7, p.483-558, 1985.

43. Johnson, L.F.; Arroyo, T. Germination of oospores of Pythium ultimum in the cotton rhizosphere. Phytopathology, St. Paul, v.73, n.12, p.1620-1624, 1983.

44. Johnstone, M.B. Canopy and leaf gas exchange accompanying Pythium root rot of lettuce and chrysanthemum. 2001.126p. Thesis (Master of Science in Horticulture), University of Guelph, Guelph, Ontario, Canada.

45. Johnstone, M.; Chatterton, S.; Sutton, J.; Grodzinski, B. Photosynthesis, net carbon gain, and growth of hydroponic bell peppers (Capsicum annuum 'Cubico') following root infection by Pythium aphanidermatum. Canadian Journal of Plant Pathology, Ottawa, v.25, n.4, p.427), 2003. (Abstract).

46. Johnstone, M.B.; Chatterton, S.; Sutton, J.C.; Grodzinski, B. Net carbon gain and growth of bell peppers, Capsicum annuum L. 'Cubico' following root infection by Pythium aphanidermatum. Phytopathology, St. Paul, v.95, n.4, p.354-361, 2005.

47. Johnstone, M.; Yu, H.; Liu, W.; Leonardos, E.; Sutton, J.C.; Grod- 
zinski, B. Physiological changes associated with Pythium root rot in hydroponic lettuce. Acta Horticulturae, (The Hague), v.635, p.67-75, 2005.

48. Jones, S.W.; Donaldson, S.P.; Deacon, J.W. Behaviour of zoospores and zoospore cysts in relation to root infection by Pythium aphanidermatum. New Phytologist, Oxford, v.117, n.2, p.289301, 1991.

49. Jung, M.C.V. The role of selected plant and microbial metabolites in the nutrient solution of closed growing systems in greenhouses. 2003. Thesis (Doctorate in Crop Science) - Swedish University of Agricultural Sciences, Uppsala.

50. Jung, V.; Chimuka, L.; Jönsson, J.Å.; Niedack, N.; Bowens, P.; Alsanius, B.W. Supported liquid membrane extraction for identification of phenolic compounds in the nutrient solution of closed hydroponic growing systems for tomato. Analytica Chimica Acta, Amsterdam, v.474, n.1, p.49-57, 2002.

51. Jung, V.; Olsson, E.; Asp, H.; Jensén, P.; Caspersen, S.; Alsanius, B.W. Response of young hydroponically grown tomato plants to phenolic acids. Scientia Horticulturae, Amsterdam, v.100, n.1, p.23-37, 2004.

52. Kamoun, S.; Huitema, E.; Vleeshouwers, V.G.A.A. Resistance to oomycetes: a general role for the hypersensitive response? Trends in Plant Science, Kidlington, v.4, n.5, p.196-200, 1999.

53. Khan, A.; Sutton, J.C.; Grodzinski, B. Effects of Pseudomonas chlororaphis on Pythium aphanidermatum and root rot in peppers grown in small-scale hydroponic troughs. Biocontrol Science Technology, Basingstoke, v.13, n.6, p.615-630, 2003.

54. Kläring, H.-P.; Grosch, R.; Nederhoff, E.; Schwarz, D. A model approach to describe the effect of root pathogens on plant growth and yield. Acta Horticulturae, The Hague, v.548, p.235-241, 2001.

55. Knee, E.M.; Gong, F-C.; Gao, M.; Tepliski, M.; Jones A.R.; Foxworthy, A.; Mort, A.J.; Bauer, W.D. Root mucilage from pea and its utilization by rhizosphere bacteria as a sole carbon source. Molecular Plant-Microbe Interactions, St. Paul, v.14, n.6, p.775784, 2001.

56. Kraft, J.M.; Endo, R.M.; Erwin, D.C. Infection of primary roots of bentgrass by Pythium aphanidermatum. Phytopathology, Worcester, v.57, n.1, p.86-90, 1967.

57. Levesque, C.A.; Harlton, C.; Decock, A.W.A.M. Identification of some oomycetes by reverse dot blot hybridization. Phytopathology, St. Paul, v.88, n.3, p.213-222, 1998.

58. Liu, W.; Sutton, J.C.; Khan, A.; Grodzinski, B. Effectiveness of five bacterial agents against root diseases caused by Pythium aphanidermatum and Pythium dissotocum in hydroponic chrysanthemum. Canadian Journal of Plant Pathology, Ottawa, v.24, n.4, p.377, 2002. (Abstract).

59. Lopes, C.A. Manejo integrado de doeças em cultivos hidropônicos. Fitopatologia Brasileira, Brasilia, v.28, (Suplemento), p.S195S197, 2003.

60. Lopes, C.A.; Zambolim, L.; Makishima, N. Doenças em cultivos hidropônicos e medidas de controle. In: Zambolim, L., Vale, F.X.R. do \& Costa, H. (Ed.). Controle de doenças de plantas: hortaliças, Viçosa, p.621-637, 2000.

61. Martin, F.N.; Loper, J.E. Soilborne plant diseases caused by Pythium spp.: ecology, epidemiology, and prospects for biological control. Critical Reviews in Plant Sciences, Boca Raton, v.18, n.2, p.111181,1999

62. Martin, R.R.; James, D.; Levesque, C.A. Impacts of molecular diagnostic techniques on plant disease management. Annual Review of Phytopathology, Palo Alto, v.38, p.207-239, 2000.
63. McCarter, S.M.; Littrell, R.H. Comparative pathogenicity of Pythium aphanidermatum and Pythium myriotylum to twelve plant species and intraspecific variation in virulence. Phytopathology, Worcester, v.60, n.2, p.264-268, 1970.

64. McPherson, G.M.; Harriman, M.R.; Pattison, D. The potential for spread of root diseases in recirculating hydroponic systems and their control with disinfection. Mededelingen Faculteit Landbouwkundige en Toegepaste Biologische Wetenschappen Universiteit, Gent, v.60, p.371-379, 1995.

65. Menzies, J.G.; Bélanger, R.R. Recent advances in cultural management of diseases in greenhouse crops. Canadian Journal of Plant Pathology, Ottawa, v.18, n.2, p.186-193, 1996.

66. Menzies, J.G.; Ehret, D.L.; Stan, S. Effect of inoculum density of Pythium aphanidermatum on growth and yield of cucumber plants grown in recirculating nutrient film culture. Canadian Journal of Plant Pathology, Ottawa, v.18, n.1, p.50-54, 1996.

67. Mojdehi, H.; Singleton, L.L.; Richardson, P.E. Histopathology of wheat seedling roots infected with Pythium arrhenomanes. Journal of Phytopathology, Berlin, v.128, p.246-256, 1991.

68. Moulin, E.; Lemanceau, P.; Alabouvette, C. Pathogenicity of Pythium species on cucumber in peat-sand, rockwool, and hydroponics. European Journal of Plant Pathology, The Netherlands, v.100, n.1, p.3-17, 1994.

69. Nemec, S. Histopathology of Pythium-infected strawberry roots. Canadian Journal of Botany, Ottawa, v.50, p.1091-1096, 1972.

70. Novikova, N.D. Basic patterns of microflora development in the environment of orbital complex Mir. Aviakosmicheskaia i Ekologicheskaia Meditsina, Abingdon,v.35, n.1, p.32-40, 2001.

71. Owen-Going, T.N. Etiology and epidemiology of Pythium root rot in bell pepper (Capsicum annuum L.) in commercial-scale and smallscale hydroponic systems. 2002. Thesis (Masters in Environmental Biology) - University of Guelph, Guelph, Ontario, Canada.

72. Owen-Going, T.N.; Beninger, C.W., Christie, B.; Sutton, J.C.; HALL, J.C. Role of phenolic compounds in epidemics of Pythium root rot (Pythium aphanidermatum) of hydroponic pepper. Canadian Journal of Plant Pathology, Ottawa, v.26, n.1, p.41-419, 2004. (Abstract).

73. Owen-Going, N.; Sutton, J.C.; Grodzinski, B. Relationships of Pythium isolates and sweet pepper plants in single-plant hydroponic units. Canadian Journal of Plant Pathology, Ottawa, v. 25, n.2, p.155-167, 2003.

74. Patrick, Z.A. Phytotoxic substances associated with the decomposition in soil of plant residues. Soil Science, Baltimore, v.111, n.1, p.13-18, 1971.

75. Paulitz, T.C. Biological control of root pathogens in soilless and hydroponic systems. HortScience, Alexandria, v.32, n.2, p.193196, 1997.

76. Paulitz, T.C.; Bélanger, R.R. Biological control in greenhouse systems. Annual Review of Phytopathology, Palo Alto, v.39, p.103133, 2001

77. Pettitt, T.R.; Finlay, A.R.; Scott, M.A.; Davies, E.M. Development of a system simulating commercial production conditions for assessing the potential spread of Phytophthora cryptogea root rot of hardy nursery stock in recirculating irrigation water. Annals of Applied Biology, Cambridge, v.132, n.1, p.61-75, 1998.

78. Pickett-Popoff, L.; Panter, K.L. Survey of Pythium and Phytophthora spp. in irrigation water used by Colorado commercial greenhouses to determine source of pathogen introduction. Phytopathology, St. Paul, v.84, n.10, p.1118, 1994. (Abstract).

79. Postma, J.; Willemsen-de-Klein, M.J.E.I.M.; Van Elsas, J.D. Effect 
of indigenous microflora on the development of root and crown rot caused by Pythium aphanidermatum in cucumber grown in rockwool. Phytopathology, St. Paul, v.90, n.2, p.125-133, 2000.

80. Punja, Z.K.; Yip, R. Biological control of damping-off and root rot caused by Pythium aphanidermatum on greenhouse cucumbers. Canadian Journal of Plant Pathology, Ottawa, v.25, n.4, p.411417, 2003.

81. Qutob, D.; Kamoun, S.; Gijzen, M. Expression of a Phytophthora sojae necrosis-inducing protein occurs during transition from biotrophy to necrotrophy. Plant Journal, Oxford, v.32, n.4, p.361373, 2002.

82. Rafin, C.; Tirilly, Y. Characteristics and pathogenicity of Pythium spp. associated with root rot of tomatoes in soilless culture in Brittany, France. Plant Pathology, London, v.44, p.779-785, 1995.

83. Raftoyannis, Y.; Dick, M.W. Effects of inoculum density, plant age, and temperature on disease severity caused by Pythiaceous fungi on several plants. Phytoparasitica, Rehovot, v. 30, n.1, p.67-76, 2002.

84. Reid, B.; Morris, B.M.; Gow, N.A.R. Calcium-dependent, genusspecific, autoaggregation of zoospores of phytopathogenic fungi. Experimental Mycology, San Diego, v.19, n.3, p.202-213, 1995.

85. Rey, P.; Benhamou, N.; Tirilly, Y. Ultrastructural and cytochemical investigation of asymptomatic infection by Pythium spp. Phytopathology, St. Paul, v.88, n.3, p.234-244, 1998.

86. Rey, P.; Nodet, P.; Tirilly, Y. Pythium F induces a minor but ubiquitous disease in tomato soilless cultures. Journal of Plant Pathology, Bari, v.79, n.3, p.173-180, 1997.

87. Robertson, G.I. Occurrence of Pythium spp. in New Zealand soils, sands, pumices, and peat, and on roots of container-grown plants. New Zealand Journal of Agricultural Research, Wellington, v.16, p.357-365, 1973.

88. Rong, G.S.; Tachibana, S. Effect of dissolved oxygen levels in a nutrient solution on the growth and mineral nutrition of tomato and cucumber seedlings. Journal of the Japanese Society for Horticultural Science, Tokyo, v.66, n.2, p.331-337, 1997.

89. Royle, D.J.; Hickman, C.J. Analysis of factors governing in vitro accumulation of zoospores of Pythium aphanidermatum on roots. I. Behaviour of zoospores. Canadian Journal of Microbiology, Ottawa, v.10, n.1, pp.151-162, 1964.

90. Runia, W.T. A review of possibilities for disinfection of recirculation water from soilless cultures. Acta Horticulturae, (The Hague), v.382, p.221-229, 1995.

91. Schnitzler, J.P.; Seitz, H.U. Rapid responses of cultured carrot cells and protoplasts to an elicitor from the cell wall of Pythium aphanidermatum (Edson) Fitzp. Zeitschrift für Naturforschung, Tübingen, v.44c, p.1020-1028, 1989.

92. Schuerger, A.C. Microbial contamination of advanced life support (ALS) systems poses a moderate threat to the long-term stability of space-based bioregenerative systems. Life Support Biosphere Science, New York, v.5, n.4, p.325-337, 1998.

93. Schuerger, A. Alternative methods for controlling root diseases in hydroponic systems. Proceedings of the $13^{\text {th }}$ Annual Conference on Hydroponics, Hydroponic Society of America, Orlando, FL, pp. 8-17, 1992.

94. Schwartz, M. Oxygenating of nutrient solution in normal and stress conditions. Soilless Culture, Wageningen, v.5, n.1, p.5-53, 1989.

95. Shokes; McCarter. Occurrence, dissemination and survival of plant pathogens in surface irrigation ponds in southern Georgia. Phytopathology, St. Paul, v.69, n.5, p.510-516, 1979

96. Stanghellini, M. Spore germination, growth, and survival of Pythium in soil. Proceedings of The American Phytopathological Soci- ety, St. Paul, v.1, p.211-214, 1974.

97. Stanghellini, M.; Burr, T.J. Germination in vivo of Pythium aphanidermatum oospores and sporangia. Phytopathology, St. Paul, v.63, n.12, p.1493-1496, 1973.

98. Stanghellini, M.; Kronland, W.C. Yield loss in hydroponically grown lettuce attributed to subclinical infection of feeder roots by Pythium dissotocum. Plant Disease, St. Louis, v.70, n.11, p.10531056, 1986.

99. Stanghellini, M.; Rasmussen, S.L. Hydroponics: a solution for zoosporic pathogens. Plant Disease, St. Louis, v.78, n.12, p.11291138, 1994.

100. Stanghellini, M.; Rasmussen, S.L.; Kim, D.H.; Rorabaugh, P.A. Efficacy of nonionic surfactants in the control of zoospore spread of Pythium aphanidermatum in a recirculating hydroponic system. Plant Disease, St. Louis, v.80, n.4, p.422-428, 1996.

101. Stanghellini, M.E.; White, J.G.; Tomlinson, J.A.; Clay, C. Root rot of hydroponically grown cucumbers caused by zoospore-producing isolates of Pythium intermedium. Plant Disease, St. Louis, v.72, n.4, p.358-359, 1988.

102. Sutton, J.C.; Evans, R. Water treatment technologies for managing root diseases in hydroponic peppers. Phase II. Final Report, Industrial Research Assistance Program, National Research Council, Ottawa., 1999. 58p.

103. Sutton, J.C.; Owen-Going, N.; Sopher, C.R.; Hall, J.C. Interactive effects of Pythium aphanidermatum and allelopathic phenolics accelerate root rot epidemics in hydroponic peppers (Capsicum annuum L.). Fitopatologia Brasileira, Brasilia, v.28, (Suplemento), S363, 2003. (Abstract 747).

104. Sutton, J.C.; Yu, H.; Grodzinski, B.; Johnstone, B. Relationships of ultraviolet radiation dose and inactivation of pathogen propagules in water and hydroponic nutrient solutions. Canadian Journal of Plant Pathology, Ottawa, v.22, n.3, p.300-309, 2000.

105. Taiz, L.; Zeiger, E. Plant physiology. $3^{\text {rd }}$ edition. Sinauer Associates Inc., Sunderland, MA, 2002.

106. Thinggard, K.; Middleboe, A.L. Phytophthora and Pythium in pot plant cultures on an ebb and flow bench with recirculating nutrient solution. Journal of Phytopathology, Berlin, v. 125, p.343-352, 1989.

107. Thomson, T.B.; Athow, K.L.; Laviolette, F.A. The effect of temperature on the pathogenicity of Pythium aphanidermatum, $P$. debaryanum, and P. ultimum. Phytopathology, Worcester, v.61,n.8, p.933-935, 1971.

108. Trujillo, E.E.; Hine, R. The role of papaya residues in papaya root rot caused by Pythium aphanidermatum and Phytophthora parasitica. Phytopathology, Worcester, v.55, n.12, p.1293-1298, 1965.

109. Tu, J.C.; Papadopoulos, A.P.; Hao, X.; Zheng, J. The relationship of Pythium root rot and rhizosphere microorganisms in a closed circulating and an open system in rockwool culture of tomato. Acta Horticulturae, The Hague, v.481, p.577-583, 1999.

110. Utkhede, R.S.; Koch, C.A.; Menzies J.G. Rhizobacterial growth and yield promotion of cucumber plants inoculated with Pythium aphanidermatum. Canadian Journal of Plant Pathology, Ottawa, v.21, n.3, p.265-271, 1999.

111. Utkhede, R.S.; Lévesque, C.A.; Dinh, D. Pythium aphanidermatum root rot in hydroponically-grown lettuce and the effect of chemical and biological agents on its control. Canadian Journal of Plant Pathology, Ottawa, v.22, n.2, p.138-144, 2000.

112. Van der Plaats-Niterink, A.J. Monograph of the genus Pythium. Studies in Mycology, No. 21. Centraalbureau Voor Schimmelcultures, Baarn, The Netherlands, 1981. 242p. 
113. Veit, S.; Worle, J.M.; Nurnberger, T.; Koch, W.; Seitz, H.U. A Novel Protein Elicitor (PaNie) from Pythium aphanidermatum induces multiple defense responses in carrot, Arabidopsis, and tobacco. Plant Physiology, Bethesda, v.127, n.3, p. 832-841, 2001.

114. Waechter-Kristensen, B.; Caspersen, S.; Adalsteinsson, S.; Sundin, P.; Jensén, P. Organic compounds and microorganisms in closed hydroponic culture: occurrence and effects on plant growth and mineral nutrition. Acta Horticulturae, The Hague, v.481, p.197204, 1999

115. Waechter-Kristensen, B.; Gertsson, U.E.; Sundin, P. Prospects for microbial stabilization in the hydroponic culture of tomato using circulating nutrient solution. Acta Horticulturae, v.361, p.382387, 1994.

116. Wakeham, A.J.; Pettitt, T.R.; White, J.G. A novel method for detection of viable zoospores of Pythium in irrigation water. Annals of Applied Biology, Cambridge, v.131, n.3, p.427-435, 1997.

117. Walker, T.S.; Bais, H.P.; Grotewold, E.; Vivanco, J.M. Root exudation and rhizosphere biology. Plant Physiology, Bethesda, v.132, n.1, p.44-51, 2003.

118. Wulff, E.G.; Pham, A.T.F.; Chérif, M.; Rey, P.; Tirilly, Y.; Hocke- nhull, J. Inoculation of cucumber roots with zoospores of mycoparasitic and plant pathogenic Pythium species: Differential zoospore accumulation, colonization ability, and plant growth response. European Journal of Plant Pathology, The Netherlands, v.104, n.1, p.69-76, 1998.

119. Zadoks, J.C.; Schein, R.D. Epidemiology and Plant Disease Management. Oxford University Press, New York, 427p, 1979.

120. Zeroni, M.; Gale, J.; Ben-Asher, J. Root aeration in a deep hydroponic system and its effect on growth and yield of tomato. Scientia Horticulturae, Amsterdam, v.19, n.3, p.213-220, 1983.

121. Zhang, W.; Tu, J.C. Effect of ultraviolet disinfection of hydroponic solutions on Pythium root rot and non-target bacteria. European Journal of Plant Pathology, The Netherlands, v.106, n.5, p.415421,2000

122. Zheng, J.; Sutton, J.C.; Yu, H. Interactions among Pythium aphanidermatum, roots, root mucilage, and microbial agents in hydroponic cucumbers. Canadian Journal of Plant Pathology, Ottawa, v.22, n.4, p.368-379, 2000.

123. Zinnen, T.M. Assessment of plant diseases in hydroponic culture. Plant Disease, St. Louis, v. 72, n.2, p.96-99, 1988. 